\title{
DARNIOS PASTATU ARCHITEKTŪROS GENOTIPAS IR FENOTIPAS
}

\author{
Jūratė Kamičaitytė-Virbašiene் ${ }^{1}$, Indrè Gražulevičiūtè-Vileniškè ${ }^{2}$ \\ Kauno technologijos universitetas, Architektūros ir kraštotvarkos katedra, \\ Studentu g. 48, 51367 Kaunas, Lietuva \\ El.paštas: ${ }^{1}$ jurate.kamicaityte@ktu.lt; ${ }^{2}$ grazuleviciute@yahoo.co.uk \\ Iteikta 20110315
}

\begin{abstract}
Santrauka. Darnus projektavimas ir darni statyba - tai vis labiau populiarejjančios ir plačiau pripažistamos aplinkos formavimo veiklos kryptys. Nors literatūroje dažnai sutinkami aplinką tausojančią pastatų architektūrą apibūdinantys terminai, tokie kaip „darni architektūra“, „ekologiška architektūra“, „žalioji architektūra“, tačiau kartu pastebimas ir nepakankamas dėmesys teoriniam darnaus vystymosi principais paremto projektavimo pagrindui: nėra pateikiamas konkretus darnios pastatų architektūros apibrèžimas, mažai skiriama dèmesio vizualiniams, estetiniams darnaus projektavimo klausimams, darnios architektūros pastatų santykiui su kontekstine aplinka, darnaus vystymosi principais paremtos architektūros kūrimo įtakai darniam užstatytos aplinkos vystymuisi platesniu mastu. Šie problemos aspektai pagrindžia straipsnio tikslą - remiantis iš gamtos mokslų perimtomis genotipo ir fenotipo sąvokomis ir jų tarpusavio sąsajomis, išryškinti svarbiausius darnios pastatų architektūros bruožus, jos vizualinės raiškos kryptis ir, remiantis Kauno miesto pavyzdžiu, susieti jas su konkrečia kontekstine aplinka.
\end{abstract}

Reikšminiai žodžiai: darnus vystymasis, darni architektūra, genotipas, fenotipas, Kaunas.

\section{Ivadas}

Darnus vystymasis pastarąji dešimtmetį tapo daugelio procesų ir veiklų siekiamybe ir mokslo darbų objektu. Mokslineje ir profesineje literatūroje, projektuose vis dažniau vartojami terminai „darni statyba“, „darnus projektavimas“, „darni architektūra“, „ekoarchitektūra“, „ekologiška architektūra“, „žalioji architektūra“. Darnaus vystymosi principais paremto aplinkos formavimo, darnaus projektavimo, darnios statybos nuostatas analizavo K. Jong-Jin ir B. Rigdon (1998), J. F. McLennan (2004), M. Roe (2007), Ch. J. Kibert (2008), J. Stuart-Murray (2007) ir daugelis kitų tyrinètojų. Visgi literatūroje dažnai pateikiami tik apibendrinti šių veiklų apibrèžimai, o pagarbos kultūriniam kontekstui, estetiškumo ir psichologinio priimtinumo kriterijus dažnai nustelbia demesys naujausioms ekologinèms technologijoms, energetiniam pastatų efektyvumui ir išteklių tausojimui. Pvz., J. Wines (2000) išskiria ekologiškos architektūros raiškos kryptis nuo ekotechnologinių sprendimų iki futuristinių architektūros ir urbanistikos fantazijų, tačiau apsiriboja tik aprašomąja analize ir nepateikia konkretaus eko- logiškos ar darnios architektūros apibrèžimo ar konkrečių rekomendacijų, kokioje aplinkoje vienokios ar kitokios krypties darni architektūra galètų būti kuriama, kaip ji sąveikautų su įvairiais kontekstais. Analizuojant darniais įvardijamus pastatų projektus, buvo pastebèta tam tikra darnios architektūros raiškos globalizacija - architektų ìkèpimo šaltiniu tampantys ekologinès gyvensenos būdai, aplinkos tausojimo idejos, pažangios technologijos iggauna tarptautini atspalvị ir naujos architektūros kontekstualumo pagrindu nebūtinai tampa pastatų formos, bylojančios vietos bendruomenèms suprantama architektūrine kalba. Šiuo požiūriu darnios architektūros objektų vizualinès raiškos simboliai tampa tarptautiniai ir turi menką ryšį su vietos kraštovaizdžio ar miestovaizdžio pobūdžiu. Kita vertus, tradicinių, vietinių medžiagų ir architektūros formų naudojimas, tinkamas kaimo aplinkoje, kelia dermès problemų miesto vizualinès aplinkos kontekste. Darnios architektūros kūrimo urbanizuotoje aplinkoje problematika yra plètojama be išsamesnio teorinio pagrindo tik pateikiant archi- 
tektūrinių projektų rinkinius su glaustais aprašymais (pvz., R. Munster, 2008). Taip pat pastebèta, kad darnios pastatų architektūros problemos paprastai yra sprendžiamos tik mikro- - pastato, pastatų komplekso, sklypo - lygmenyje. Analizę atliekant tokiame ribotame lygmenyje, sunku atsakyti ị klausimus, kur ir kokios vizualinès raiškos darnios architektūros pastatas gali būti lokalizuojamas urbanizuotoje ar gamtinèje aplinkoje, kokios ittakos jis turès aplinkos kokybei ir vystymuisi. Aptarti aspektai atskleidžia:

- apibendrintų darnaus vystymosi idejų konkretizavimo ir pritaikymo aplinkos formavimo disciplinoms reikšmę;

- būtinybę, plètojant darnios architektūros sampratą, susieti technologinę bei vizualinę plotmes ir patikslinti darnios architektūros objektų vizualinès raiškos kryptis;

- raiškos universalumo ir lokalumo santykio darnioje pastatų architektūroje problematiką;

- būtinybę išplètoti darnios architektūros dermès urbanizuotoje aplinkoje ir potencialo gerinti miesto ivaizdį skirtingų charakteristikų urbanizuotose teritorijose problematiką. Tyrimai, susiejantys darnios pastatų architektūros potencialą mikro(sklypo, jo artimos aplinkos) ir makro- (miesto ar kitos gyvenamosios teritorijos) lygmenyse, būtų naudingi tiek praktineje projektavimo veikloje, tiek strategiškai integruojant architektūros kūrimą ¡̇ darnaus užstatytos aplinkos vystymosi procesus. Iškeltos problemos leidžia suformuluoti straipsnio tiksla - išryškinti svarbiausius darnios pastatų architektūros bruožus, jos vizualinès raiškos ypatumus bei vizualinès dermès ịvairioje kontekstineje aplinkoje galimybes. Šioms galimybėms tyrinèti ir iliustruoti buvo suformuluotos hipotetinès darnios architektūros raiškos kryptys miesto makro- lygmenyje Kauno pavyzdžiu. Igyvendinant straipsnio tikslą - susiejant, apibendrinant ir papildant ankstesnių tyrimų (Kamičaitytè-Virbašienė, Gražulevičiūtè-Vileniškè 2009, 2010; Gražulevičiūtė-Vileniškè ir kt. 2011) rezultatus - kaip analizès priemone buvo pasitelkta gamtos moksluose naudojama genotipo ir fenotipo sąvokų ir jų tarpusavio ryšio analogija, atlikta Lietuvos ir užsienio literatūros apžvalga, žvalgomieji tyrimai vietose ir topografinès medžiagos analizè.

\section{Architektū ros ir genetikos analogijos ir jų taikymas užstatytos aplinkos tyrimams}

Norint suvokti abstrakčių darnaus vystymosi idejų pritaikymo konkrečioje projektavimo, planavimo veikloje galimybes, šių idejjų ittaką architektūros vizu- alinei raiškai ir darnios architektūros ryšị su lokaliu kontekstu, pasitelkiama analogija tarp architektūros ir genetikos disciplinų. Genetika - gamtos mokslų disciplina, biologijos mokslų šaka, tirianti genus ir paveldimumo dèsningumus. Genetikos sričiai priskiriami terminai „genotipas“, „fenotipas“ ir jų tarpusavio ryšių pobūdis vis dažniau perkeliami ị kitas tyrimų sritis. Kraštovaizdžius ir užstatytą aplinką suvokiant kaip nuolat besivystančius organizmus, šios sąvokos gali būti taikomos ir žmogaus gyvenamajai aplinkai analizuoti. Vienas tokios analizès pavyzdžių - J. Grima ir P. Reyes inicijuotas Miesto genomo projektas, paremtas didžiausią itaką miestų visuomenèms ir formai turinčių veikejjų sociologinemis apklausomis ir interviu, kuriuo siekiama iššifruoti socialinius kodus, lemiančius vienokią ar kitokią miestų formą (Urban... 2011). K. Zaleckis ir I. Matijošaitienè (2010) atliko Kauno centrinès dalies socialinio bei erdvinio kodo ir jo pokyčiu 1935-1988 m. tyrimus taikydami erdvès sintaksès metodiką. Tyrimais siekta išsiaiškinti, kaip planavimo dokumentų, nuosavybės formų ir kt. pokyčiai veikia miesto socialinę ir erdvinę struktūrą.

Literatūroje genotipas yra apibrèžiamas kaip visų organizmo genų, apibūdinančių jo paveldimas savybes, visuma. Gamtos mokslai pripažịsta, kad genų lemiamas paveldimumas reikšmingas, tačiau ne vienintelis veiksnys, nuo kurio priklauso organizmų išvaizda ir elgsena. Konkretaus organizmo charakteristikoms įtakos turi aplinka ir atsitiktiniai veiksniai (Blamire 2000; National... 2004). Genų ir aplinkos nulemtus išorinius organizmo požymius apibūdina fenotipas - išorinis genotipo požymis. Analizuojant darnaus vystymosi principų taikymą architektūroje galima išskirti du aspektus, nagrinètinus pasitelkiant genotipo ir fenotipo analogiją:

1. Pamatinè darnaus vystymosi idejja - plètra, tenkinanti dabartinès kartos poreikius, neužkertant kelio savo poreikių tenkinti ateities kartoms (Report... 1987) - būtų suvokiama kaip darnios architektūros genotipas. Jos konkretizavimas, atsižvelgiant ị architektūrinio projektavimo ypatumus, formuluojant darnios architektūros sampratą, išskiriant jos kūrimo principus, identifikavimo kriterijus ir vizualinès raiškos kryptis, būtų suprantamas kaip fenotipas.

2. Apibendrinta darnios architektūros samprata ir universalios jos vizualinès raiškos kryptys taip pat gali būti analizuojamos kaip genotipas. Darnios architektūros apraiškos konkrečioje aplinkoje, paveiktos konkrečiu jos gamtinių, sociokultūrinių, socioekonominių ir kitų sąlygų, būtų suvokiamos kaip fenotipas. 


\section{Darnios architektūros samprata kaip darnaus vystymosi koncepcijos fenotipas}

\section{Darnaus vystymosi koncepcijos konkretinimas}

Darnaus vystymosi idejos oponentai pastebi, kad ji yra pernelyg apibendrinta ir prieštaringa. Akcentuojama, kad šio žodžių junginio demenys "tvarumas“ (toks būtų tikslesnis angliško termino sustainable vertimas) ir „,ystymasis“ ar „plètra“ prieštarauja vienas kitam (Roe 2007). Siekiant darnaus vystymosi koncepciją taikyti moksliniuose tyrimuose ir praktineje veikloje, tenka ją nuolatos plètoti ir konkretinti. Pavyzdžiui, pradinè koncepcijos orientacija ị ekonominio augimo ir aplinkosaugos tikslų suderinamumą buvo išplètota $\mathfrak{i}$ tris tarpusavyje susijusias dimensijas - darnų socialinị ir ekonominị vystymąsi bei aplinkos apsaugą. Apibendrinti darnaus vystymosi siekiai konkretinami, transformuojami pagal kontinentų, regionų specifiką. Po Pasaulio viršūnių susitikimo Rio de Žaneire valstybès buvo paskatintos kurti nacionalines darnaus vystymosi strategijas. Šiuo pagrindu buvo parengta ir Lietuvos nacionalinè darnaus vystymosi strategija (Lietuvos... 2009). Taip pat gali būti rengiamos mažesnio regiono, rajono, miesto lygmens darnaus vystymosi strategijos, valdymo planai.

Analizuojant architektūrinio projektavimo ir aplinkos formavimo klausimus, svarbus specializuotas darnaus vystymosi koncepcijos taikymas - darnios architektūros, darnaus projektavimo, darnios statybos, darnios kraštovaizdžio architektūros ir pan. koncepcijos, atspindinčios XX a. pabaigos-XXI a. pradžios visuomenių požiūrị ì pageidautinas architektūros savybes ir jos santykị su aplinka. Pageidautinų, žmogui priimtinų architektūros bruožų klausimas buvo svarstomas ir sprendžiamas dar senovés pasaulyje, žmogui vis labiau išsilaisvinant iš gamtos prieglobsčio (Wines 2000). Tai gerai išreiškia garsioji Vitruvijaus triada - stiprumas, naudingumas, grožis - atspindinti antropocentrinị požiūrị i architektūrą. XX a. modernizmo architektūrinès raiškos globalizacija, laipsniškas ekologiniu problemu, kultūrinès ivvairovès, vietos identiteto ir praeities paveldo verčiu suvokimas paskatino integralesnio architektūros pagrindimo paieškas: F. L. Wright išplètojo organiškosios architektūros koncepciją, kurioje siekè maksimalios harmonijos su gamtine aplinka, projektavo pastatus iš vietinių medžiagų, nevengè remtis etninėmis tradicijomis, sieke sukurti ir išreikšti pastato vidinių erdvių ir išorès ryši (Minkevičius 1971); F. Hunderwasser siūlè atsisakyti pramoninès gamybos ir standartizacijos architektūroje, grižžti prie gamtinių medžiagų ir pastatus kurti vietoje, spontaniškai, be liniuotes ar braižymo lentos (Rand 2007); J. Jacobs (1961) kritikavo modernistini laisvo plano gyvenamųjų rajonų užstatymą, laike ji nehumanišku. Šiuolaikiniuose debatuose architektūros sampratos ir raiškos klausimais ryškeja ekologinis dèmuo - įsisąmoninama, kad „tuščios vietos“ Žemèje apskritai nèra. Lygiagrečiai išryškejja socialinis humanistinis, vietos tapatumo respektavimo ir pletojimo tikslai. Architektūra imama suvokti ne kaip statybos menas, bet kaip aplinkos formavimo būdas ir priemone (Stauskas 2009). Architektūriniam projektavimui pritaikyta išplètota darnaus vystymosi koncepcija, kitaip tariant, koncepcijos fenotipas leidžia anksčiau minètas idejjas sujungti ir integraliai plètoti. Būtent integralus žinomų architektūros savybių, tokių kaip patogumas, ekologiškumas, tvirtumas, kontekstualumas, plettojimas gali peraugti ị naują darnios architektūros kokybę. Tokiu atveju darnia pastatų architektūra turètų būti laikoma (Kamičaitytè-Virbašienè, GražulevičiūtèVileniškè 2009, 2010):

- visapusiškai darnaus vystymosi principais - tokiais kaip materialios ir nematerialios gerovès siekis, teisingumas dabarties ir ateities kartų atžvilgiu, teisingumas visuomenèse ir tarp visuomenių, kultūrinès ir biologinès ịvairovès apsauga ir palaikymas, atsargumas priimant sprendimus, reiškinių tarpusavio priklausomybès pripažinimas (Throsby 2002) - paremta architektūra;

- architektūros darnumas turètų būti užprogramuojamas kūrimo etape ir pasireikšti per visą jos gyvavimo laikotarpi - nuo objekto projektavimo ir teritorijos paruošimo statybai darbų iki griovimo ar objekto renovacijos;

- darni architektūra turètų ne tik būti tvari, ilgaamžiška ir tausojanti aplinką, bet ir kontekstuali, estetiška bei psichologiškai priimtina;

- darnios architektūros pastatas turètų skatinti darnų aplinkos ir visuomenès vystymąsi - išteklių ir energijos tausojimą, socialinę sanglaudą - prisidèti prie gyvenimo kokybės gerinimo plačiąja prasme. Formuluojant bendrus darnios architektūros objektų vertinimo kriterijus, reikètu pasitelkti nuostatas, susijusias su darniu vystymusi, kuris suvokiamas kaip antropoekocentrine paradigma, kai aplinkos tausojimas laikomas svarbia problema, žmonijos rūpesčiu todèl, kad sveika aplinka gali prisideti prie bendros žmonijos gerovès ir didesnès laimès (Thompson 2007), darnios architektūros objektą suvokiant kaip naują aplinkos ir žmogaus darnios sąveikos rezultatą. Tokiu atveju darnios architektūros objektas turètų integruoti ir tenkinti ekologinius bei ekonominius (medžiaginių, energetinių ir teritorinių erdvinių išteklių naudojimo projektavimas įvertinant antropoekosistemų talpumo rodiklius), ergonominius (objekto funkcionalumas ir tinkamumas veiklai), sociokultūrinius (bendruomenès poreikių ịvertinimas ir identiteto jausmo stiprinimas, aplinkos savitumo respektavimas ir kultūros paveldo 
racionalus naudojimas) ir estetinius bei psichologinius (išraiškingos, kompoziciškai harmoningos, originalios, vizualiai atpažistamos ir semantiškai t̨prasmintos architektūros objektų kūrimas ir statyba) kriterijus.

\section{Darnios architektūros vizualinès raiškos galimybės ir kryptys}

Aplinką tausojančios architektūros kūrimas tampa vis populiaresnis ir sulaukia vis didesnio architektūros kritiku dèmesio. Architektūros kritikai, pvz., J. Wines (2000), R. Munster (2008), pateikia platų spektrą projektų ir igyvendintų objektų, paremtų darnaus vystymosi principais ar jų dalimi, pavyzdžių. Išanalizavus šiuos pavyzdžius, atsiskleidžia darnios architektūros objektų vizualinès raiškos įvairove. Galima daryti prielaidą, kad darnios architektūros raišką lemia vidiniai ir išoriniai veiksniai. Vidiniams architektūros raišką lemiantiems veiksniams galima priskirti architekto idejją ir ịkvejpimo šaltinị, projekto biudžetą, pastato tipologiją ir techninius reikalavimus. Išoriniai veiksniai apimtų aplinkos, kurioje projektuojama, ypatumus ir vertę, sociokultūrinị kontekstą, galiojančių teisinių dokumentų nuostatas ir atsakingų instituciju požiūrị bei darnaus projektavimo ir statybos principus (Kamičaitytė-Virbašienè, Gražulevičiūtè-Vileniške 2010). Remiantis šia prielaida, išanalizavus literatūrą ir darniais ar ekologiškais įvardijamus pastatus ar pastatų projektus (Wines 2000; Munster 2008; Reali... 2009; Skorupskas 2009; Konkurso... 2010), buvo nustatyti ryšiai tarp pastato architektūrinès raiškos, mastelio ir supančios aplinkos pobūdžio ir, remiantis J. Wines (2000), išskirtos šešios aktualiausios darnios pastatų architektūros vizualinès raiškos kryptys, pradedant estetišku ir psichologiškai priimtinu aplinką tausojančių technologijų pateikimu ir baigiant darnios architektūros bei istorinès urbanizuotos aplinkos harmonijos siekiu. Trumpas kiekvienos krypties aprašas ir charakteringi pavyzdžiai pateikti 1 lenteleje.

Darnios architektūros raiškos analizė atskleidžia tokios architektūros universalumo ir lokalumo santykio problematiką. Kai kurie objektai, pavyzdžiui, R. Piano, Jean-Marie Tjibaou kultūros centras Naujoje Kaledonijoje, H. Hollein - Abteibergo muziejus, architektų studijos „Erdvės norma“ projektuotas kompleksas ,Jūra, smèlis, vejjas“ Juodkranteje, akivaizdžiai iaugę i̇ savo medžiaginị ir kultūrinị kontekstą ir yra unikalūs pastatai, kurių nebūtų įmanoma sèkmingai perkelti ị kitą kontekstą. Pastato kaip kraštovaizdžio dalies koncepcijai atstovaujantys analizuoti pavyzdžiai taip pat tiesiogiai susiję su kontekstine aplinka, nes šiuo atveju pagrindinis architekto uždavinys yra padaryti savo kūrinį bemaž nematomą ar pabrèžti vertingiausias kraštovaizdžio savybes. Analizuoti ekotechnologinès krypties pastatai pasižymi universalia raiška, o pagrindinis ir dažnai vienintelis veiksnys, siejantis juos su kontekstu, yra vietos klimatinès sąlygos, kurių visapusiu panaudojimu dažnai paremtos ekologinès technologijos. Analizuoti pastato-sodo ir gamtinių formų interpretavimo koncepcijoms atstovaujantys statiniai taip pat pasižymi gana universalia architektūrine raiška.

\section{Universalių raiškos krypčių ir kontekstinès aplinkos sąsajos kaip darnios architektūros fenotipas}

\section{Darnios architektūros krypčių ir kontekstinès aplinkos santykio matrica}

Pagrindinis darnios architektūros pastato, kaip ir bet kurio kito architektūros objekto, derinimo su kraštovaizdžiu principas yra kontekstualumas. Darnios architektūros pastatų santykio su kontekstine aplinka analizè atskleide įvairių šios architektūros raiškos krypčių ir kontekstinès aplinkos tipų sąveikos rezultatų i̇vairovę. Pastebèta, kad darnios architektūros pastatai gali vizualiai neišsiskirti iš kontekstinès aplinkos tapti fonu kitiems pastatams ar išraiškingoms gamtos formoms, kraštutiniu atveju tokie objektai gali būti ir visiškai nematomi. Darnios architektūros pastatai gali papildyti vizualinę aplinką ir kartu su kitais pastatais kaip lygiaverčiai jiems formuoti kraštovaizdžio vizualinị tipą arba gali dominuoti vizualinëje erdveje ir ryškiai skirtis iš kontekstinès aplinkos. Apibendrintų darnios architektūros krypčių apraiškų konkrečioje aplinkoje analizè leidžia plètoti darnios architektūros genotipo ir fenotipo santykio problematiką remiantis kontekstualumo kategorija.

Naujai kuriamos architektūros ir kontekstinès aplinkos santykis nèra naujas nagrinejjimo objektas. Visgi verta pastebèti, kad daugiausiai demesio šiuo požiūriu yra skiriama naujos architektūros dermei vertingoje istorinèje miesto aplinkoje (Jurkštas 1994; Bučas 2003; Navickienè 2006), o naujos architektūros potencialas gerinti ivvairaus charakterio užstatytos aplinkos kokybę, paryškinti ar keisti jos charakterị sulaukia mažiau dèmesio. Darnios architektūros raiškos krypčių santykio su aplinka galimybes galima tyrinèti taikant identiteto indekso teoriją (Turner 1998), kuri kitų autorių išskirtas kompozicinio pastato santykio su istorine urbanizuota aplinka kategorijas - panašumą, neutralumą ir kontrastą (Jurkštas 1994), kopiją, imitaciją, inovaciją (Bučas 2001), retrospektyvią, harmoningą ir novatorišką architektūros raišką (Warren et al. 1998) - leidžia išreikšti kiekybine išraiška ir taikyti ịvairaus pobūdžio aplinkoje. Kontekstualumas, remiantis identiteto indekso teorija, traktuojamas kaip kiekybinis pastato dermès su aplinka matas. Remiantis T. Turner (1998), architektūrinio objekto kiekybinis kontekstua- 
1 lentelè. Darnios architektūros pastatų vizualinès raiškos kryptys

Table 1. Trends of visual expression of sustainable buildings

\begin{tabular}{|c|c|c|c|c|}
\hline $\begin{array}{l}\text { Raiškos krypties } \\
\text { pavadinimas ir trumpas } \\
\text { apibūdinimas }\end{array}$ & $\begin{array}{l}\text { Būdinga } \\
\text { aplinka }\end{array}$ & $\begin{array}{l}\text { Būdingas } \\
\text { mastelis }\end{array}$ & $\begin{array}{l}\text { Charakteringi } \\
\text { pavyzdžiai }\end{array}$ & $\begin{array}{l}\text { Vizualinès raiškos } \\
\text { atitikmenys } \\
\text { Lietuvoje }\end{array}$ \\
\hline $\begin{array}{l}\text { 1. Aplinką tausojančių } \\
\text { technologijų estetizavimo } \\
\text { koncepcija, kartais } \\
\text { vadinama ekotechnologine. } \\
\text { Bandymai suteikti estetišką } \\
\text { išraišką ekologiškoms } \\
\text { technologijoms ir } \\
\text { inovacijoms. Tokie pastatai } \\
\text { savo architektūrine raiška } \\
\text { labai primena stiklinius } \\
\text { modernizmo pastatus }\end{array}$ & $\begin{array}{l}\text { ¿vairi } \\
\text { urbanizuota ir } \\
\text { neurbanizuota } \\
\text { aplinka }\end{array}$ & $\begin{array}{l}\text { svyruoja } \\
\text { nuo didelių } \\
\text { visuomeninių } \\
\text { pastatų ir } \\
\text { kompleksų iki } \\
\text { gyvenamujų } \\
\text { namų }\end{array}$ & $\begin{array}{l}\text { - Th. Herzog, namas Rėgensburge, } \\
\text { Vokietija, 1977-1979 m. } \\
\text { - "Jourda and Perraudin", Lijono } \\
\text { miesto Tarptautinis mokslų } \\
\text { centras, Prancūzija, 1989-1992 m. } \\
\text { - "Innovarchi“, ateities namas „Future } \\
\text { House“ Naujajame Pietų Velse, } \\
\text { Australija, } 2006 \text { m. }\end{array}$ & $\begin{array}{l}\text { - "PHL Architects AS" } \\
\text { (Danija), } \\
\text { "Archprojektas", verslo } \\
\text { centras „Green Hall“ } \\
\text { Vilniuje, } 2009 \text { m. } \\
\text { - „A. Ambraso architektų } \\
\text { biuras", "Swedbank" } \\
\text { administracinis pastatas } \\
\text { Vilniuje, } 2009 \text { m. }\end{array}$ \\
\hline $\begin{array}{l}\text { 2. Pastato-sodo koncepcija, } \\
\text { paremta sodo integracija i } \\
\text { pastatą }\end{array}$ & $\begin{array}{l}\text { urbanizuota } \\
\text { aplinka, } \\
\text { priemiestinès } \\
\text { teritorijos }\end{array}$ & $\begin{array}{l}\text { mažo } \\
\text { mastelio } \\
\text { objektai, } \\
\text { dažniausiai - } \\
\text { gyvenamieji } \\
\text { namai }\end{array}$ & $\begin{array}{l}\text { - "Ushida-Findlay partnership“, } \\
\text { gyvenamasis namas „Soft and Hairy } \\
\text { House“, Tsukuba, Japonija, } 1994 \text { m. } \\
\text { - "R\&Sie”, "Lost in Paris“ gyvenamasis } \\
\text { namas Paryžiuje, } 2009 \text { m. } \\
\text { - "Marc Kohler Architects”, } \\
\text { gyvenamasis namas „House ljburg“ } \\
\text { su integruotu sodu, Amsterdamas, } \\
\text { Olandija, } 2008 \text { m. }\end{array}$ & $\begin{array}{l}\text { - Architektu studijos } \\
\text { „Reali erdvë“ parengtas } \\
\text { tipinis gyvenamojo } \\
\text { namo projektas } \\
\text { „Saulès namas III" }\end{array}$ \\
\hline $\begin{array}{l}\text { 3. Pastato-kraštovaizdžio } \\
\text { koncepcija, paremta } \\
\text { architektūros integravimu i } \\
\text { supantį kraštovaizdi }\end{array}$ & $\begin{array}{l}\text { vertinga } \\
\text { gamtinè } \\
\text { aplinka }\end{array}$ & $\begin{array}{l}\text { didelio masto } \\
\text { objektai, } \\
\text { architektūriniai } \\
\text { kompleksai }\end{array}$ & $\begin{array}{l}\text { - E. Ambasz, Schlumberger tyrimų } \\
\text { laboratorijos, Austin, Teksasas, } \\
\text { projektas, } 1983 \text { m. } \\
\text { - G. Peichl, EFA, Radijo ir palydovinè } \\
\text { stotis, Aflenz, Austrija, } \\
\text { 1976-1979 m. } \\
\text { - "ACME", Rathaus terasų } \\
\text { daugiafunkcis kompleksas, } \\
\text { jungiantis gyvenamąją, komercinę } \\
\text { funkcijas ir žaliąsias viešąsias erdves, } \\
\text { Weilburg, Vokietija, projektas } \\
2009 \text { m. }\end{array}$ & $\begin{array}{l}\text { - Koncepciją iš dalies } \\
\text { atitinka architektų } \\
\text { studijos „Reali erdve” } \\
\text { parengtas tipinis } \\
\text { gyvenamojo } \\
\text { namo projektas } \\
\text { "Saulès namas IV“ }\end{array}$ \\
\hline $\begin{array}{l}\text { 4. Gamtinių formų } \\
\text { interpretavimo koncepcija. } \\
\text { Tokia architektūra semiasi } \\
\text { ¡kvėpimo iš gamtos formų } \\
\text { ir kosmologijos }\end{array}$ & $\begin{array}{l}\text { priemiestinè } \\
\text { aplinka, } \\
\text { kaimo } \\
\text { kraštovaizdis, } \\
\text { gamtiné } \\
\text { aplinka }\end{array}$ & $\begin{array}{l}\text { mažo } \\
\text { mastelio } \\
\text { objektai, } \\
\text { dažniausiai - } \\
\text { gyvenamieji } \\
\text { namai }\end{array}$ & $\begin{array}{l}\text { " "Jersey Devil", sraigès pavidalo } \\
\text { namas, Forked River, Niudžersis, } \\
\text { JAV, } 1972 \text { m. } \\
\text { - P. Vetsch, „Devyni namai", Dietikon, } \\
\text { Šveicarija, } 1993 \text { m. }\end{array}$ & $\begin{array}{l}\text { - R. Skorupsko } \\
\text { (2009 m.) aprašytas } \\
\text { V. Gardauskienès ir } \\
\text { D. Kriaučiūnienės } \\
\text { projektuotas } \\
\text { gyvenamasis namas, } \\
\text { statybos vieta ir data } \\
\text { nenurodytos }\end{array}$ \\
\hline $\begin{array}{l}\text { 5. Tradicinių statybos } \\
\text { technologijų ir } \\
\text { architektūrinių formų } \\
\text { pritaikymo koncepcija, } \\
\text { paremta vietinių medžiagu } \\
\text { ir statybos technologijų } \\
\text { pritaikymu, etninės, } \\
\text { liaudiškos } \\
\text { architektūros formų } \\
\text { interpretavimu }\end{array}$ & $\begin{array}{l}\text { gamtinis ir } \\
\text { kaimo } \\
\text { kraštovaizdis }\end{array}$ & $\begin{array}{l}\text { mažo } \\
\text { mastelio } \\
\text { objektai, } \\
\text { dažniausiai - } \\
\text { gyvenamieji } \\
\text { namai }\end{array}$ & $\begin{array}{l}\text { - D. Lea, studija „West Country“, } \\
\text { Anglija, } 1985 \text { m. } \\
\text { - R. Piano, Jean-Marie Tjibaou } \\
\text { kultūros centras, Naujoji Kaledonija, } \\
\text { 1992-1998 m. }\end{array}$ & $\begin{array}{l}\text { " „ARCHES", poilsio namai } \\
\text { "Nakcižibis" Varénos } \\
\text { rajone, } 2009 \text { m. }\end{array}$ \\
\hline $\begin{array}{l}\text { 6. Darnios architektūros ir } \\
\text { istorinės urbanizuotos } \\
\text { aplinkos vizualinès } \\
\text { harmonijos koncepcija, } \\
\text { paremta istorinès aplinkos } \\
\text { vizualinio } \\
\text { vientisumo, evoliucijos ir } \\
\text { praturtinimo siekiais }\end{array}$ & $\begin{array}{l}\text { istorinis miesto } \\
\text { centras, } \\
\text { istoriniai } \\
\text { priemiesčiai }\end{array}$ & $\begin{array}{l}\text { svyruoja } \\
\text { nuo didelių } \\
\text { visuomeninių } \\
\text { pastatų ir } \\
\text { kompleksų iki } \\
\text { gyvenamųụ } \\
\text { namų, masteli } \\
\text { lemia aplinkos } \\
\text { charakteris }\end{array}$ & $\begin{array}{l}\text { - H. Hollein, Abteibergo muziejus, } \\
\text { Monchenglabdach, Vokietija, } \\
\text { 1972-1982 m. } \\
\text { - G. Bohm, Saarbrucken rūmų } \\
\text { rekonstrukcija, Vokietija, } \\
\text { 1981-1989 m. } \\
\text { - „ECDM“, Louis Blanc socialiniai } \\
\text { būstai Paryžiuje, 2004-2006 m. }\end{array}$ & $\begin{array}{l}\text { " „Erdvės norma“, } \\
\text { kompleksas „Jūra, } \\
\text { smėlis, vėjas” } \\
\text { Juodkrantèje, } 2008 \text { m. } \\
\text { " „Uostamiesčio } \\
\text { projektai“, „Jūros } \\
\text { vartu“" plètros projektas } \\
\text { Klaipèdoje, } \\
\text { 2007-2008 m. }\end{array}$ \\
\hline
\end{tabular}


lumas aplinkos atžvilgiu gali būti vertinamas procentais: nedidelè procentinè vertè, pavyzdžiui 10-20 proc., rodo, kad objektas ryškiai kontrastuoja su kontekstine aplinka; 40-60 proc. ivertinimas rodo, kad objektas panašus ị savo kontekstinę aplinką; įvertinimas, artimas 100 proc., rodo, kad objektas yra labai panašus ị savo kontekstinę aplinką arba jai identiškas. Siekiant tiksliau nustatyti vizualini kontekstualumą, remiantis minètu principu, procentais gali būti vertinamas atskiru objekto savybiu - mastelio, medžiagų, architektūrinio stiliaus ar krypties, spalvų - kontekstualumas ir bendra jo verte būtų laikomas šių verčių vidurkis.

Visi mineti darnios architektūros pastato ir aplinkos santykio atvejai - tapatumas, panašumas ar skirtingumas - negali būti vertinami vienareikšmiškai teigiamai ar neigiamai. Jie vienokią ar kitokią reikšmę igauna lyginant su aplinkos erdvinio formavimo koncepcija, kuri turètų būti suformuluota jau rengiant teritoriju planavimo dokumentus. Jei vietai, kurioje projektuojamas pastatas, tokio pobūdžio dokumentas neparengtas, projektuojamo pastato santykio su aplinka koncepciją ir iš jos kylančias sąlygas pastatui projektuoti reikètų nustatyti ikiprojektinių tyrimų etape. Analizuojant darnios architektūros pastatų architektūrinès raiškos kryptis ir jų santykị su įvairia kontekstine aplinka, buvo parengta apibendrinta hipotetinè pagrindinių darnios architektūros pastato raišką lemiančių savybių - dydžio arba mastelio, medžiagų, architektūrinio stiliaus ir spalvų - rekomenduojamų identiteto indekso procentinių verčių skirtingoje kontekstinejje aplinkoje matrica (2 lentelè) (KamičaitytèVirbašienè, Gražulevičiūtè-Vileniškè 2010). Ši matrica, kurioje kiekvienam darnios architektūros raiškos krypties ir kontekstinès aplinkos tipo santykio atvejui suteikiami atitinkami indeksai, šiame tyrime traktuojama kaip darnios architektūros raiškos krypčių fenotipas. Matrica gali būti naudojama kaip pagalbinè priemoné projektuojant darnios architektūros pastatus. Matricos duomenys taip pat gali būti integruojami $\mathfrak{i}$ teritorijos erdvinio formavimo koncepciją.

\section{Hipotetinès darnios architektūros raiškos kryptys Kauno mieste}

Ieškant būdų harmonizuoti urbanizuotos aplinkos vystymąsi, kokybiškos, kontekstualios, turinčios savo identitetą ir aplinką tausojančios architektūros kūrimo urbanizuotose teritorijose galimybès yra itin aktualios. Siekiant, kad darnios architektūros ir kraštovaizdžio architektūros kūrimas taptų integralia miestų vystymosi dalimi, svarbu parengti darnios pastatų architektūros vizualinès raiškos rekomendacijas įvertinant aplinkos charakteristikas, savitumą, paveldosauginius aspektus.
Siekiant iliustruoti darnios architektūros raiškos krypčių ir konkretaus urbanistinio konteksto santykio kaip darnios architektūros fenotipo aspektą, buvo nustatytos darnios pastatų architektūros vizualinès dermès hipotetinès galimybès ir raiškos kryptys Kauno miesto urbanizuotoje aplinkoje $m a$ kro-lygmenyje: išskirtos skirtingų charakteristikų ir įvaizdžio miesto dalys ir pateikiamos kokybinès bei kiekybinès rekomendacijos darniai architektūrai kurti jose (1 pav., 2 lentelè). Atlikti tyrimai leidžia teigti, kad Kauno miesto istorinio centro, istorinių priemiesčių ir buvusios tvirtoves kultūros paveldo teritorijose, kaip saugotino miestovaizdžio charakterio zonose, galimos prioritetines IU-1 ir IU-6 darnios architektūros pastatų vizualinès raiškos kryptys. IU-1 krypčiai būdingas istorinio užstatymo mastelio respektavimas, tačiau yra galimybè kontrastuoti medžiagiškumo, stiliaus ir spalvos lygmenyse, o IU-6 kryptis pasižymi visų vizualinių savybių respektavimo būtinybe. Vertingų kaimo kraštovaizdžio reliktų, esančių urbanizuotoje aplinkoje, teritorijose (Linkuvos ir Aukštosios Fredos dvaro sodybos teritorijose) taip pat siūloma naudoti prioritetines IU-1 ir IU-6 kryptis ir papildomą VU-2 kryptị. Siekiant šiuos reliktus išsaugoti kaip svarbius Kauno miestovaizdžio savitumo formantus, naudotinai VU-2 krypčiai turètų būti būdingas gamtinių ir antropogeninių kraštovaizdžio komponentų mastelio ir spalvos respektavimas, tačiau suteikiama galimybè kontrastuoti medžiagiškumo ir stiliaus lygmenyse. Teritorijoms, užstatytoms gyvenamaisiais mažaaukščiais namais, visuomeniniais ir komerciniais objektais, siūlomos prioritetinès VU-1, PU-1, VU-2 ir PU-2 kryptys. VU-1 ir PU-1 krypčių atveju galimas darnios architektūros pastatų vizualinę raišką lemiančių visų savybių skirtingų lygių kontrastas, o PU-2 krypties atveju galimas tik atskirų savybių - medžiagos ir stiliaus - kontrastas. Tai ypač aktualu periferinèse miesto teritorijose, kur vyrauja smulkios sąskaidos užstatymas žalumos fone. Teritorijose, užstatytose gyvenamaisiais daugiaaukščiais namais, visuomeniniais ir komerciniais objektais siūloma naudoti prioritetines VU-1 ir PU-4 kryptis. PU-4 krypties atveju galimas visų savybių kontrastas, išskyrus masteli; tai taip pat aktualu miesto periferinèse zonose, prieigų teritorijose. Pramoninių ir komercinių objektų teritorijose siūlomos prioritetinès VU-1 ir PU-1 kryptys, o komercinių, visuomeniniu objektų teritorijoms, kurioms būdinga gyvenamoji funkcija - VU-1, PU-1 ir PU-4 kryptys. Papildomai būtina pažymèti, kad Kauno miesto želdynų teritorijų darnios infrastruktūros vystymo klausimui detalizuoti būtinas atskiras tyrimas. 
2 lentelè. Pagrindinių darnios architektūros krypčių raišką lemiančių savybių identiteto indekso verčių skirtingose kontekstinèse aplinkose hipotetinè matrica

Table 2. The hypothetical matrix of possible identity indexes of the main features of sustainable buildings in a different contextual environment

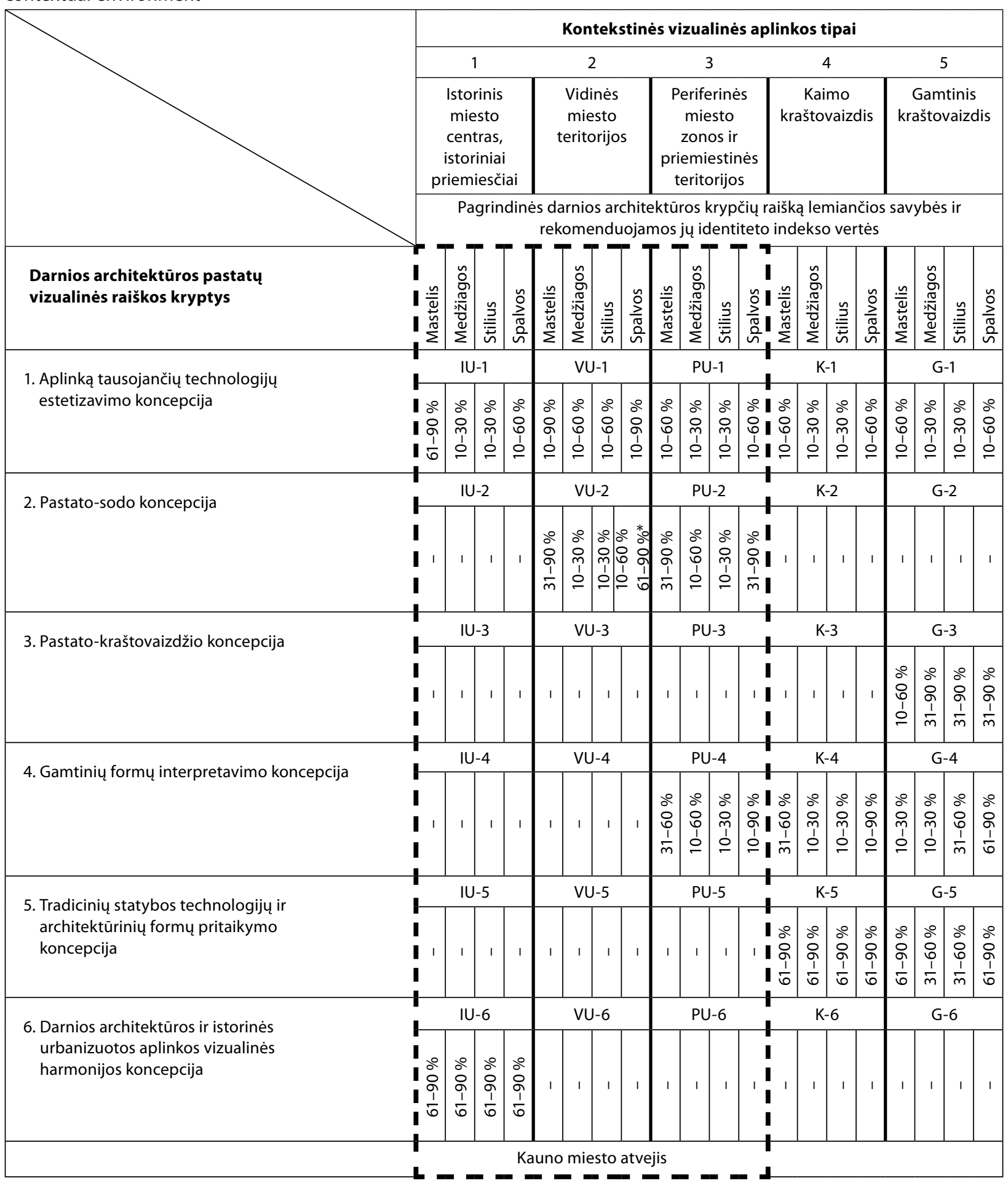

Paaiškinimai: identiteto indekso vertè 10-30 proc. rodo, kad statomas pastatas vizualiai išsiskiria iš kontekstinès aplinkos nagrinèjamu aspektu, verte 31-60 proc. rodo, kad pastatas vizualiai panašus i kontekstinę aplinką nagrinejjamu aspektu; vertè 61-90 proc. rodo, kad darnios architektūros pastatas vizualiai identiškas kontekstinei aplinkai nagrinèjamu aspektu;

* antroji reikšmė taikytina vertingų kaimo kraštovaizdžio reliktų teritorijose Kauno mieste. 

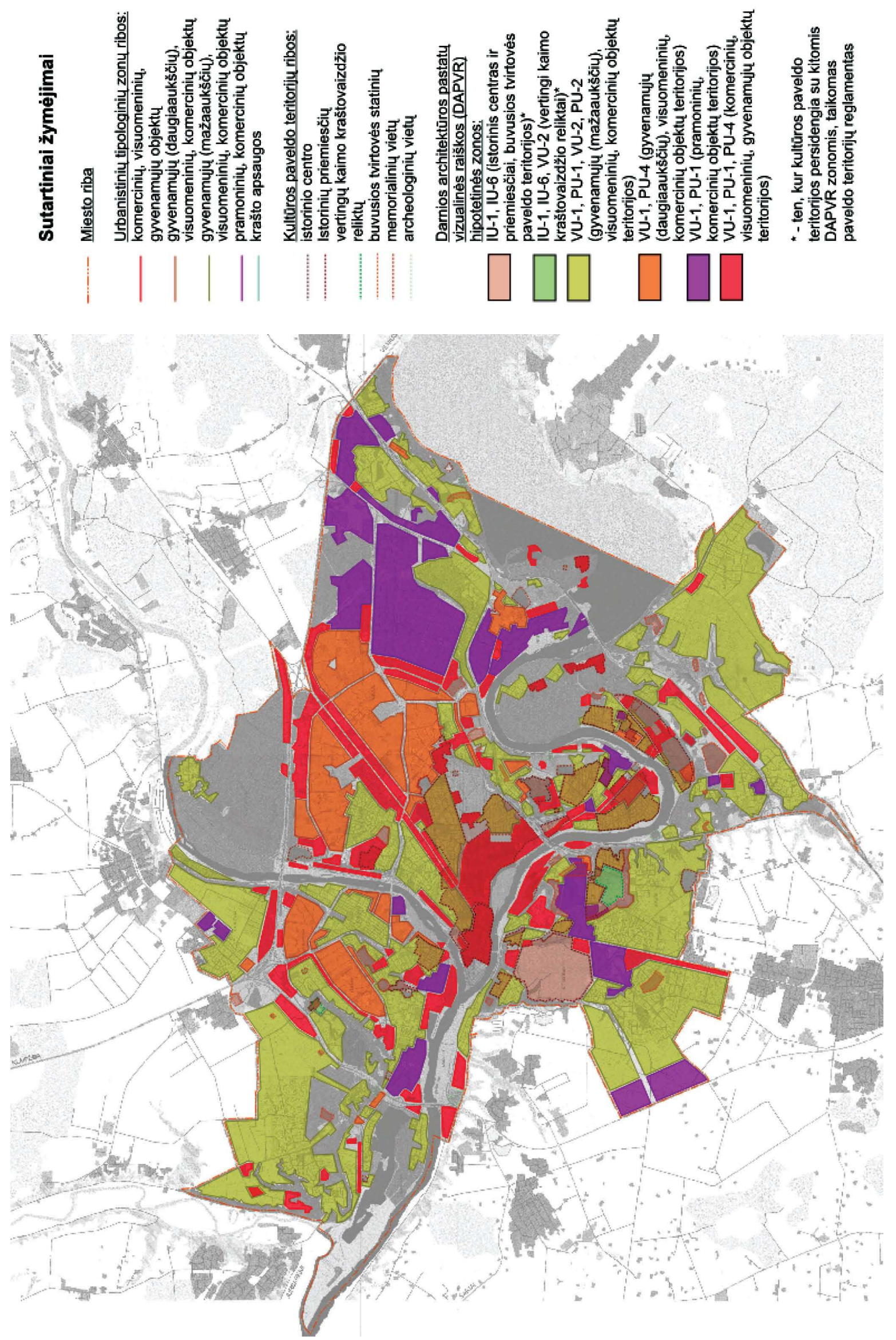


\section{Išvados}

1. Siekiant išplètoti teorinị darnaus pastatų projektavimo pagrindą, paranku pasitelkti gamtos moksluose vartojamas genotipo ir fenotipo sąvokas. Tokiu atveju darnaus vystymosi ideja ir apibendrinti principai traktuojami kaip genotipas, o ju pritaikymas architektūrinio projektavimo srityje - kaip fenotipas. Apibendrinta darnios architektūros samprata, universalios jos vizualinès raiškos kryptys taip pat gali būti traktuojamos kaip genotipas, o jų apraiškos konkrečioje kontekstinëje aplinkoje kaip fenotipas.

2. Darnaus vystymosi principais paremtas pastatu projektavimas ir statyba kaip specializuota darnaus vystymosi koncepcijos taikymo sritis - darnaus vystymosi fenotipas - turetų remtis darnios architektūros samprata. Darni architektūra - tai visapusiškai darnaus vystymosi principais paremta architektūra, kurios darnumas užprogramuojamas kūrimo etape ir pasireiškia per visą jos gyvavimo laikotarpị. Darni architektūra turètų būti ne tik tvari, ilgaamžiška, tausojanti aplinką, kontekstuali, estetiška bei psichologiškai priimtina, bet ir veikti kaip katalizatorius - skatinti darnų aplinkos ir visuomenès vystymąsi. Tyrimas atskleidè darnaus vystymosi idejomis paremtos pastatų architektūros raiškos ịvairovę ir nevienareikšmiškumą, pradedant modernizmui artima aplinką tausojančių technologijų estetizavimo koncepcija ir baigiant postmodernia darnios architektūros bei istorinès urbanizuotos aplinkos vizualinès harmonijos, paremtos istorinès aplinkos vizualinio vientisumo, evoliucijos ir praturtinimo siekiais, koncepcija.

3. Analizuojant darnios architektūros vizualinès raiškos krypčių universalumo, kaip genotipo, ir lokalumo, kaip fenotipo, problematiką, paranku analizuoti kompozicini pastato santykị su aplinka, išskiriant ir kiekybiškai ịvertinant konkrečių pastato savybių, tokių kaip mastelis, medžiagos, stilius, spalviniai sprendimai, ir kontekstinès aplinkos santykį. Išskiriant minètų darnios architektūros pastato savybių i̇verčio tapatumo, panašumo ir skirtingumo lygmenis ir juos susiejant su darnios architektūros vizualinès raiškos kryptimis bei skirtingo charakterio urbanizuotos aplinkos zonomis, galima gauti hipotetines darnios pastatų architektūros vizualinès raiškos rekomendacijas skirtingu naudojimo tipų ir miestovaizdžio pobūdžio miesto dalyse.

4. Kauno atveju siūlomos tokios hipotetinès prioritetinès darnios pastatų architektūros vizualinès raiškos kryptys skirtingo naudojimo ir ịvaizdžio miesto teritorijose: Kauno istorinio centro ir priemiesčių, buvusios tvirtovès paveldo teritorijose - aplinką tausojančių technologijų estetizavimo koncepcija ir darnios architektūros bei istorinès urbanizuotos aplinkos vizualinès harmonijos koncepcija; vertingų kaimo kraštovaizdžio reliktų, esančių Kauno mieste, teritorijose greta minètų dviejų krypčių papildomai siūloma pastato-sodo koncepcija; gyvenamųjų mažaaukščių, visuomeninių ir komercinių objektų teritorijose - aplinką tausojančių technologijų estetizavimo koncepcija ir pastato-sodo koncepcija; gyvenamųjų daugiaaukščių, visuomeninių ir komercinių objektų ir komercinių, visuomeninių bei gyvenamųjų objektų teritorijose - aplinką tausojančių technologijų estetizavimo koncepcija ir gamtinių formų interpretavimo koncepcija (periferinèse miesto zonose); pramoninių ir komercinių objektų teritorijose - aplinką tausojančių technologijų estetizavimo koncepcija.

\section{Literatūra ir šaltiniai}

Blamire, J. 2000. Genotype and phenotype definition [interaktyvus], [žiūrèta $2011 \mathrm{~m}$. vasario 17 d.]. Prieiga per internetą: <http://www.brooklyn.cuny.edu/bc/ahp/BioInfo/GP/ Definition.html>.

Bučas, J. 2001. Kraštotvarkos pagrindai. Kaunas: Technologija.

Gražulevičiūtè-Vileniškè, I.; Ražauskaite, A.; Ažukaitė, L.; Bartininkaite, V.; Kulbokaitè, L.; Kameneckas, J. 2011. Darnaus vystymosi principais paremtas kraštovaizdžių formavimas urbanizuotose teritorijose, iš Miestų želdynu formavimas: mokslo darbai 1(8): 52-65.

Jacobs, J. 1961. The Death and Life of Great American Cities. New York: Vintage Books.

Jong-Jin, K.; Rigdon, B. 1998. Introduction to Sustainable Design. Michigan: The University of Michigan, National Pollution Prevention Center for Higher Education.

Jurkštas, V. 1994. Senamiesčiu regeneracija. Architektūros harmonizavimo problema. Vilnius: Technika.

Kamičaitytė-Virbašienė, J.; Gražulevičiūtè-Vileniškè, I. 2009. Darnios architektūros kūrimo urbanizuotoje aplinkoje prielaidos, Urbanistika ir architektūra [Town Planning and Architecture] 33 (Priedas/Supplement): 36-373.

Kamičaitytè-Virbašienè, J.; Gražulevičiūtè-Vileniškè, I. 2010. Miscellaneous environmental visual impacts of sustainable buildings, in Proceedings "Advanced construction: the $2^{\text {nd }}$ international conference". Kaunas: Technologija, 48-53.

Kibert, Ch. J. 2008. Sustainable Construction: Green Building Design and Delivery. Hoboken: John Wiley \& Sons.

Konkurso „Už darnią plètrą" projektai 2007- 2009. 2010. Vilius: Darnios plètros akademija.

Lietuvos Respublikos vyriausybes nutarimas Nr. 1247 „Dèl Lietuvos Respublikos Vyriausybès 2003 m. rugsejo 11 d. nutarimo" Nr. 1160 „Dèl Nacionalinès darnaus vystymosi strategijos patvirtinimo ir igyvendinimo" pakeitimo. 2009. Vilnius.

McLennan, J. F. 2004. The Philosophy of sustainable Design. Washington: Ecotone Publishing Company LLC.

Minkevičius, J. 1971. Architektūros kryptys užsienyje. Vilnius: Mintis. 
Munster, R. 2008. Eco Architecture. Urban Style. Koln: Evergreen.

National Center for Biotechnology Information. What is a genome 2004 [interaktyvus], [žiūrèta $2011 \mathrm{~m}$. vasario 17 d.]. Prieiga per internetą: <http://www.ncbi.nlm.nih. gov/About/primer/genetics_genome.html>.

Navickienè, E. 2006. Nauja architektūra istorineje aplinkoje: kūrimo patirtis. Vilnius: Technika.

Rand, H. 2007. Hundertwasser. Koln: Taschen.

Reali erdve. Ekologiškų namu projektai. 2009 [interaktyvus], [žiūrèta $2011 \mathrm{~m}$. vasario $17 \mathrm{~d}$.]. Prieiga per internetą: $<$ http://www.realierdve.lt/index.php?option=com_conten $\mathrm{t} \&$ view $=$ article\&id=205\&Itemid=69\&lang $=\mathrm{lt}>$.

Report of the World Commission on Environment and Development 1987 [interaktyvus], [žiūrèta $2011 \mathrm{~m}$. vasario 17 d.]. Prieiga per internetą: <http://www.un.org/documents/ga/res/42/ares42-187.htm>.

Roe, M. 2007. Landscape and Sustainability: an Overview, in Benson, J. F.; Roe, M. Landscape and Sustainablity. Abingdon: Taylor \& Francis, 1-15.

Skorupskas, R. 2009. Kai kurie koncepcijos „Namas be namo" realizacijos probleminiai aspektai, iš Konferencijos „Subalansuotos plètros idejju raiška architektūroje ir teritoriju planavime" pranešimu medžiaga. Kaunas: Technologija, 180-200.

Stauskas, V. 2009. Kai kurie šiuolaikinès architektūrologijos aspektai, Urbanistika ir architektūra [Town Planning and Architecture] 33(Priedas/Supplement): 270-278. doi:10.3846/1392-1630.2009.33.270-278

Stuart-Murray, J. 2007. The Practice of Sustainable Landscape Architecture, in Benson, J. F.; Roe, M. (Ed.). Landscape and Sustainablity. Abingdon: Taylor \& Francis, 222-235.

Throsby, D. 2002. Economics and Culture. Cambridge: Cambridge University Press.

Thompson, I. 2007. The Ethics of Sustainability, in Benson, J. F.; Roe, M. (Ed.). Landscape and Sustainablity. Abingdon: Taylor \& Francis, 16-35.

Turner, T. 1998. Landscape Planning and Environmental Impact Design. Abingdon: Routledge.

Urban Genome Project 2011 [interaktyvus], [žiūrèta $2011 \mathrm{~m}$. vasario $17 \mathrm{~d}$.]. Prieiga per internetą: $<$ http://urbangenomeproject.org/home >.

Warren, J.; Worthington, J.; Taylor, S. 1998. Context: New Buildings in Historic Settings. Oxford: Architectural Press.

Wines, J. 2000. Green Architecture. Koln: Taschen.

Zaleckis, K.; Matijošaitiene, I. 2010. Social-spatial Code of Kaunas Downtown Area within Complexity of Interactions, in Proceedings of "Advanced construction: the $2^{\text {nd }}$ international conference", Kaunas: Technologija, 87-94.

\section{PHENOTYPE AND GENOTYPE OF SUSTAINABLE BUILDING ARCHITECTURE}

\section{J. Kamičaitytė-Virbašienė, I. Gražulevičiūtė-Vileniške}

Abstract. Sustainable design and construction are the trends of environmental design and management gaining an increasing acknowledgement and popularity. The definitions targeted at the environmentally friendly building architecture, such as "sustainable architecture", "ecological architecture", "green architecture" are widespread in literature; however, the analysis of literature has also revealed the insufficient attention to the theoretical basis of the application of the principles of sustainability to the field of architectural design: no unified definition of sustainable building architecture is provided, insufficient attention is devoted to the visual and aesthetic aspects of sustainable design, to the links of sustainable buildings with the contextual environment, and the wider influence of the sustainable architectural design on the development of the built environment is also rarely analysed. These aspects of the problem justify the aim of the article, which is to highlight the main features of sustainable building architecture, the main trends of its visual expression, and to link them with the particular contextual environments using the example of Kaunas city. The entire analysis is carried out using analogies from natural sciences - genotype and phenotype - and the character of their interconnections.

Keywords: sustainable development, sustainable architecture, genotype, phenotype, Kaunas.

\section{JŪRATĖ KAMIČAITYTÉ-VIRBAŠIENĖ}

Assoc. Prof., Dept of Architecture and Land Management, Kaunas University of Technology, Studentu g. 48, 51367 Kaunas, Lithuania.E-mail: jurate.kamicaityte@ktu.lt

Research interests: landscape visual quality analysis, evaluation and regulation by means of environmental design, methods of planned activity or object visual impact assessment, analysis of social preferences evaluating landscape visual quality and use of the analysis results in territory planning.

\section{INDRE் GRAŽULEVIČIŪTE்-VILENIŠKĖ}

Lecturer, Dept of Architecture and Land Management, Kaunas University of Technology, Studentu g. 48, 51367 Kaunas, Lithuania.E-mail: grazuleviciute@yahoo.co.uk

Research interests: preservation and development of historic environment, economic aspects of built heritage. 